\title{
The congruency between self and brand
}

\begin{abstract}
Nonik K., NINGRUM, Universitas Sarjanawiyata Tamansiswa, Jalan Kusumanegara 157 Yogyakarta Indonesia, nonik.kusumaningrum@ustjogja.ac.id

Sri, AYEM,
\end{abstract}

Universitas Sarjanawiyata Tamansiswa, Jalan Kusumanegara 157 Yogyakarta Indonesia, sri.ayem@ustjogja.ac.id

\begin{abstract}
The purpose of this study was to investigate the relationships between actual self congruence, brand attachment, brand involvement, and brand loyalty. This study applied quantitative explanatory research. Purposive random sampling was used as sampling technique. A number of 200 respondents, which have familiarity to a certain brand, was asked to fill in the questionnaire as primary survey data. The findings show that actual self-congruence significantly positive affects brand involvement, brand attachment, and brand loyalty. Future study should include ideal self-congruent to compare whether actual or ideal self-congruence which has a stronger correlation on brand involvement, attachment, and also brand loyalty. This study provides a basis for firms to have better understanding of actual self-congruence roles on building customer brand involvement, brand attachment, and also brand loyalty.
\end{abstract}

Keywords: actual self-congruence, brand involvement, brand attachment, and brand loyalty.

JEL Classification: M31.

\section{Introduction}

The objectives of this study was to examine whether actual selfcongruence is a good predictor of brand attachment, brand involvement, and brand loyalty. Recently, companies start to realize the importance of building and maintaining relationship between customers-self and brand. This relationship occurs when customers interact with the brand. Brand is personalized as having emotion, thought, and also willingness. It can form customers' attitude through customer life cycle, social network, and also culture (Fournier, 1998). Having a symbolic meaning, brand can represent, communicate, and aslo transform customers-self-identity, whether as an individual or part of a community (Solomon, 2013; Swaminathanet al., 2007 and 
Arnold \& Thompson, 2005). Customers self is connected with the brand by identification of the similarity between customer self-concept and brand personality through association, self-concept representation, and also evaluation process (Chaplin \& John, 2005). By using brand which has similarity with their self, customers will have positive feeling toward the brand, and will be attached, involved, and loyal (Mahjoubet al., 2015; Malar et al, 2011; and Brakuset al, 2009).

Malar et al (2011) defined self-concept as cognitive and affective understanding of who and what customers perceive their self, and congruity occurs when there are similarities between the personalities perceived by customer towards the brand with their self-concept. Nowadays, companies prefer to build personality of the brand by using model, which can represent customers actual self in order to build similarity between customers actual self and brand personality, which is called as actual self-congruence. Studies conducted by Mahjoub et al. (2015) and Malar et al. (2011) showed that actual self-congruence significantly positive affects brand involvement, brand attachment and brand loyalty. Brand involvement is picturized as mild effect and brand attachment as strong effect. Brand involvement explains how the brand can be seen as relevant and brand attachment as a strong emotional bond toward the brand. Whereas, loyalty toward the brand is described as customer repurchase behaviors (Brakus et al., 2009).

This study applied quantitative explanatory research. Purposive random sampling was used as sampling technique. A number of 200 respondents which have familiarity to a certain brand was asked to fill in the questionaire as primary survey data. The findings show that actual self congruence significantly positive affects brand involvement, brand attachment, and brand loyalty. Future study should include ideal self congruence variable in order to compare whether actual self congruence or ideal self congruence has a greater impact on brand involvement, brand attachment, and brand loyalty. Finally, this study provides a basis for firms to have better understanding of actual self congruence roles on building customers' brand attachment, brand involvement, and brand loyalty.

\section{Literature Review, Hipotheses Development, and Research Method}

\subsection{Literature Review}

Self-conceptis defined as cognitive and affective understanding of who and what ones-self is. Actual self-conceptis defined as perceived of reality of who and what ones-self actually is. Self-congruence occurs when brand's personality that ones-self has or want to have have similarity with ones-self-concept. 
Specifically, actual self reflects perceived of similarity between who and what ones-self actually is and the brand's personality (Malar et al, 2011). Zaichkowsky (1985) defines involvement as perceive of relevance of an object based on need, value, and interest. The concept of object refers to brand perceived by customers. Therefore, brand involvement is defined as perceive relevant of a brand. Park et al (2010) defined brand attachment as strong connection between customer and the brand. In other words, brand attachment is conceptualized as a bond that is connecting ones-self and the brand. Bond is mental representation that is involved thought and feeling about brand. Brand attachment is consist of brand self-connection and brand prominence. Oliver (1999) defines loyalty as commitment to repurchase product of service consistently in the future, therefore causing repurchase of the brand, eventhough marketing effort and situational condition potentially leads to switching behavior.

\subsection{Hipothesis Development}

Self-expansion theory stated that people are motivated to behave as the way they perceive themselves (Malar et al., 2011). In term of brand involvement, customers will be involved with the brand when they see that the brand's personality relevant, match, or suitable with their actual self concept. Research conducted by Mahjoubet al. (2015) found that actual self congruence significantly affects brand involvement. Furthermore, this research formulate hipotesis as follow:

\section{H1. Actual self congruence significantly positive affects brand involvment}

Self verivication theory suggested that people will be motivated to verify, validate, and maintain their self concept (Malar et al., 2011). In term of brand attachment, customers will be attached with the brand when they emotionally feel incomplete without the brand because they need the brand to be part of and to represent their self concept. Research conducted by Malar et al. (2011) showed that actual self congruence has positive and significant effect on brand attachment. Moreover, this research formulate hipotesis as follow:

\section{H2. Actual self congruence significantly positive affects brand attachment}

Cognitive-consistency theory says that people tend to be consistent with their behavior because inconsistencies lead to inconvenience and tension (Malar 
et al., 2011). In the context of brand loyalty, customers repurchase the same brand because they are trying to be consistent. Consistency shaped through congruency between customers' actual-self and the brand's personality. Research conducted by Mahjoub et al. (2015) found that actual self-congruence significantlypositif affects brand loyalty. Therefore, this study formulate hipotesis as follow:

\section{H3. Actual self congruence significantly positif affects brand loyalty.}

\subsection{Research Method}

This study applied quantitative explanatory research. The unit of analysis of this study is customers which have familiarity to a certain brand. The object of this study is 55 brands. This study involved 1 exogenous variable that is actual self congruence, and 3 endogeneous variables those are brand involvement, brand attachement, and brand loyalty.

The population of this study is customers of a brand. Sample of this study is customers of 55 brands. Purposive random sampling is used as sampling technique. There is only one criteria applied, customers which have familiarity to a certain brand. A number of 200 respondents were asked to fill in the questionaire as primary survey data.

Primary data was used in this study. The data was obtained from self administered survey. This study applied five range of likert scale from 1 to 5 . In this study, actual self congruence defined as perceived fitness of one-self and a brand; brand involvement defined as perceived relevance of a brand;brand attachment described as a strong relation between one-self and brand; and brand loyalty defined as commitment to repurchase the same brand in the future. The items of this research questionairewere adopted from previous studies. Actual self congruence was adopted from research conducted by Kumar \&Nayak (2014); brand involvement was adopted from research conducted by Zaichkowsky (1985); brand attachment was adopted from research conducted by Park et al. (2010); and brand loyalty was adopted from research coducted by Chaudury\& Holbrook (2001).

Utilizing maximum likelihood estimator of structural equation model, the data is analyzed based on measurement model, structural model, and goodness of fit index. Measurement model was used to analyze the construct validity and reliability; structural model to measure the impact of exogeneous to endogeneous variables; and goodness of fit index to know the fitness of the model and the data (Wijanto, 2008) 
1. Tables

Table 1. Measurement Model

\begin{tabular}{|c|c|c|c|c|c|}
\hline $\begin{array}{l}\text { Observed } \\
\text { Variables }\end{array}$ & $\begin{array}{c}\text { Standardized } \\
\text { Loading Factor } \\
(\geq .5)\end{array}$ & $\mathbf{R}^{2}$ & Error Variance & t-Value $(\geq 1.96)$ & Conclusion \\
\hline \multicolumn{6}{|c|}{ ACTUAL SELF CONGRUENCE } \\
\hline ASC1 & .79 & .62 & .38 & $* *$ & \multirow{5}{*}{ Valid } \\
\hline ASC2 & .84 & .71 & .30 & 12.81 & \\
\hline ASC3 & .83 & .69 & .31 & 12.61 & \\
\hline ASC4 & .83 & .69 & .31 & 12.64 & \\
\hline$\sum$ & 3.29 & 2.71 & 1.30 & & \\
\hline \multicolumn{2}{|c|}{$\mathrm{CR}(\geq .7)$} & \multicolumn{2}{|c|}{.89} & \multirow{2}{*}{\multicolumn{2}{|c|}{ Reliable }} \\
\hline \multicolumn{2}{|c|}{$\operatorname{VE}(\geq .5)$} & \multicolumn{2}{|c|}{.68} & & \\
\hline \multicolumn{6}{|c|}{ BRAND ATTACHMENT } \\
\hline BA1 & .78 & .61 & .39 & $* *$ & \multirow{5}{*}{ Valid } \\
\hline BA2 & .73 & .53 & .46 & 9.94 & \\
\hline BA3 & .62 & .38 & .62 & 8.32 & \\
\hline BA4 & .71 & .50 & .50 & 9.57 & \\
\hline$\sum$ & 2.84 & 2.03 & 1.97 & & \\
\hline \multicolumn{2}{|c|}{$\mathrm{CR}(\geq .7)$} & \multicolumn{2}{|c|}{.80} & \multirow{2}{*}{\multicolumn{2}{|c|}{ Reliable }} \\
\hline \multicolumn{2}{|c|}{$\operatorname{VE}(\geq .5)$} & \multicolumn{2}{|c|}{.51} & & \\
\hline \multicolumn{6}{|c|}{ BRAND INVOLVEMENT } \\
\hline BI1 & .80 & .64 & .36 & $* *$ & \multirow{7}{*}{ Valid } \\
\hline $\mathrm{B} 12$ & .78 & .61 & .39 & 11.53 & \\
\hline $\mathrm{BI} 3$ & .65 & .42 & .58 & 9.34 & \\
\hline BI4 & .74 & .55 & .45 & 11.83 & \\
\hline BI5 & .63 & .40 & .61 & 8.96 & \\
\hline BI6 & .78 & .61 & .39 & 11.52 & \\
\hline$\sum$ & 4.38 & 3.22 & 2.78 & & \\
\hline \multicolumn{2}{|c|}{$\mathrm{CR}(\geq .7)$} & \multicolumn{2}{|c|}{.87} & \multirow{2}{*}{\multicolumn{2}{|c|}{ Reliable }} \\
\hline \multicolumn{2}{|c|}{$\operatorname{VE}(\geq .5)$} & \multicolumn{2}{|c|}{.54} & & \\
\hline \multicolumn{6}{|c|}{ BRAND LOYALTY } \\
\hline BL1 & .88 & .77 & .23 & $* *$ & Valid \\
\hline
\end{tabular}


HOLISTICA Vol 10, Issue 1, 2019

\begin{tabular}{|c|c|c|c|c|}
\hline $\mathrm{BL} 2$ & .64 & .41 & .59 & 9.53 \\
\hline BL3 & .84 & .71 & .29 & 12.95 \\
\hline BL4 & .60 & .36 & .64 & 8.83 \\
\hline$\sum$ & 2.96 & 2.25 & 1.75 & \\
\hline \multicolumn{2}{|c|}{$\mathrm{CR}(\geq .7)$} & \multicolumn{2}{|c|}{.83} & \multirow{2}{*}{ Reliable } \\
\hline \multicolumn{2}{|c|}{$\operatorname{VE}(\geq .5)$} & \multicolumn{2}{|c|}{.56} & \\
\hline
\end{tabular}

**) Default Program

Source: Ningrum\&Ayem, 2018

Table 2. Structural Model

\begin{tabular}{lcccccc}
\hline Hypotheses & $\begin{array}{c}\text { Relationship } \\
\text { Direction }\end{array}$ & $\begin{array}{c}\text { Standardized } \\
\text { Loading Factor }\end{array}$ & $\begin{array}{c}\text { t-Value } \\
\text { 1.96) }\end{array}$ & Sig. & $\mathbf{R}^{\mathbf{2}}$ & Conclusion (Ha) \\
\hline H1. ASC to BI & $(+)$ & .16 & 1.99 & Yes & .03 & Supported \\
H2. ASC to BA & $(+)$ & .88 & 10.97 & Yes & .77 & Supported \\
H3. ASC to BL & $(+)$ & .42 & 5.16 & Yes & .18 & Supported \\
\hline
\end{tabular}

Source: Ningrum\&Ayem, 2018

Table 3. Goodness of Fit Index

\begin{tabular}{|c|c|c|c|c|c|c|}
\hline $\begin{array}{l}\text { Degree of } \\
\text { Freedom }\end{array}$ & $\begin{array}{c}\text { Chi-Square } \\
\left(X^{2}\right)\end{array}$ & $\begin{array}{c}\text { Sig. } \rho(> \\
0.05)\end{array}$ & $(0.08 \geq \mathrm{RMSEA} \geq 0.05)$ & $\begin{array}{c}C F I \\
(\geq 0.90)\end{array}$ & $\begin{array}{c}\text { GFI } \\
(\geq 0.90)\end{array}$ & Conclusion \\
\hline 112 & 142.75 & .10 & .029 & .99 & .93 & Good Fit \\
\hline
\end{tabular}




\section{Figures}

Figures 1. Standardized Loading Factor

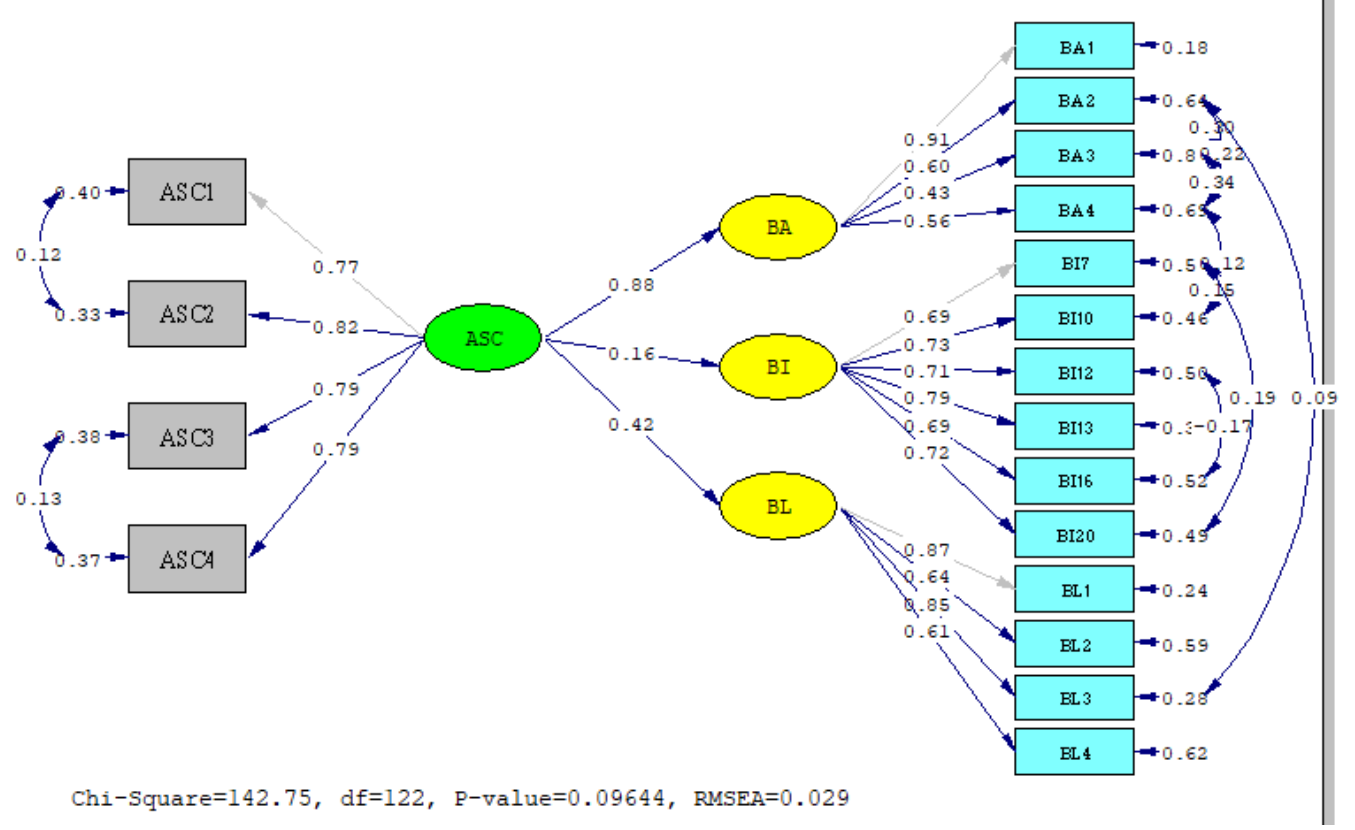

Figures 2. t-value

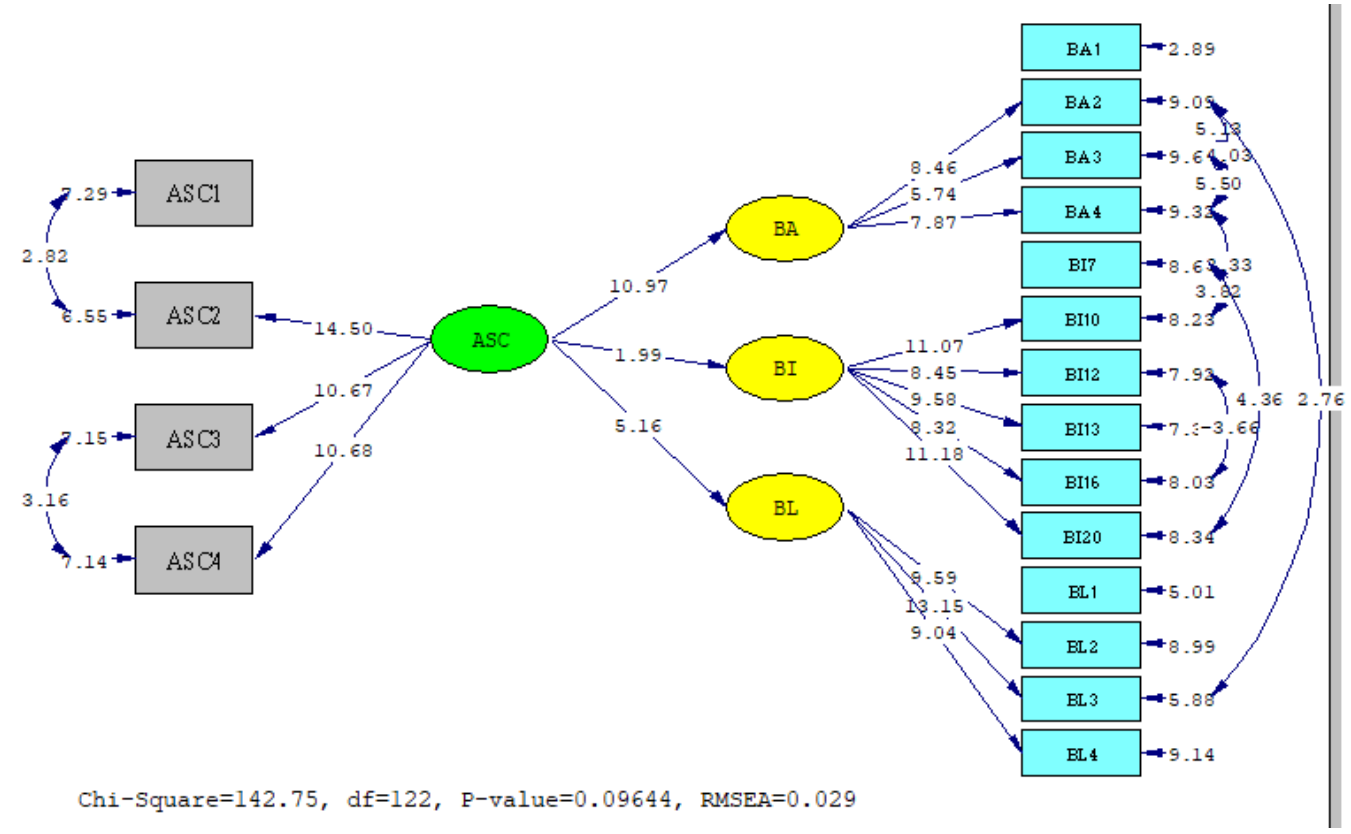

Source: Ningrum\&Ayem, 2018 


\section{Results}

Result shows that 55 brands was choosen by respondents. A number of 200 respondents are involved; 88 respondents are man and 122 respondents are woman; 5 respondents are technicians, 7 respondents are professionals, 22 respondents are entrepreneurs, 26 respondents have other professions, and 138 respondents are bachelor students; 7 respondents are master/doctoral graduates, 15 respondents are bachelor degree graduate, 17 respondents are vocational school graduates, and 161 respondents are high school graduates; 8 respondents are married with no kids, 20 respondents are married with kids, and 162 respondents are not married; 12 respondents spent $>$ Rp $3.5 \mathrm{~m}, 18$ respondents spent between $\mathrm{Rp} 2.5 \mathrm{~m}$ to $\mathrm{Rp} 3.5 \mathrm{~m}$ rupiahs, 50 respondents spent $\mathrm{Rp} 1.2 \mathrm{~m}$ - Rp $2.4 \mathrm{~m}$, and the last 120 respondents spent <Rp $1.2 \mathrm{~m}$.

Based on Table 1, it can be concluded that this research construct validity and reliability are good with standardized loading factors $\geq .5$, t-value $\geq 1.96$, construct reliability $(C R) \geq .7$, and variance extracted $(V E) \geq .5$. Based on Table 2 , it can also be seen that all hipotesis are supported. The relationship direction are all positive with $t$-value $\geq 1$.96. It means that actual self congruence significantly positive affects brand involvement, brand attachment, and also brand loyalty. Finally, as it is presented at Table 3, model has a good fit with sig. $\rho>.05, \mathrm{CFI}$ $\geq .90$, and $\mathrm{GFI} \geq .90$.

\section{Discussion, and Conclusions}

The aims of this study is to examine the effect of actual self congruence on brand attachment, brand involvement, and brand loyalty. Finding shows that actual self congruence significantly positive affects brand involvement, brand attachment, and brand loyalty. This finding implies that actual self congruence is the strongest predictor of brand attachment, followed by brand loyalty and brand involvement.

\section{References}

[1] Arnould, Eric J., \& Price, Linda L. (1993). River Magic: Extraordinary Experience and the Extended Service Encounter. Journal of Consumer Research, pp. 24-45.

[2] Brakus, J. Josko., Schmitt, Bernd H., \&Zarantonello, Lia. (2009). Brand Experience: What Is It? How Is It Measured? Does It Affect Loyalty? Journal of Marketing, pp. 52-68.

[3] Chaplin, Lan Nguyen.,\& John, Deborah Roedder. (2005). The Development of Self-Brand Connections in Children and Adolescents. Journal Of Consumer Research, pp. 119-129. 
[4] Chaudhuri, Arjun.,\& Holbrook, Morris B. (2001). The Chain of Effects from Brand Trust and Brand Affect to Brand Performance: The Role of Brand Loyalty. Journal of Marketing, pp. 81-93.

[5] Fournier, Susan (1998). Consumers and Their Brands: Developing Relationship Theory in Consumer Research. Journal of Consumer Research, pp. 343-373.

[6] Kumar, Vikas.,\&Nayak, Jogendra K. (2014). The Roles of Self Congruity and Functional Congruity in Influencing Tourists' Post Visit Behaviour. An International Journal of Akdeniz University Tourism Faculty, pp. 24-44.

[7] Mahjoub, Hossein.,Kordnaeij, Asadollah., \&Moayad, Fereshteh M. (2015). The Effect of Self-Congruency on Customer Behavior and Involvement. International Journal of Marketing Studies, pp.139-147.

[8] Malär, Lucia.,Krohmer, Harley., Hoyer, Wayne D. \&Nyffenegger, Bettina. (2011). Emotional Brand Attachment and Brand Personality: The Relative Importance of the Actual and the Ideal Self, Journal of Marketing, pp. 35-52.

[9] Oliver, Richard L. (1993). Whence Consumer Loyalty? Journal of Marketing, pp. 33-34.

[10] Park, C. Whan., Maclnnis, Deborah J., Priester, Joseph., Eisingerich, Andreas B. \& Lacobucci, Dawn. (2010). Brand Attachment and Brand Attitude Strength: Conceptual and Empirical Differentiation of Two Critical Brand Equity Drivers.Journal of Marketing, pp. 1-17.

[11] Solomon, Michael R. (2013). Consumer Behavior: Buying, Having, and Being tenth edition. Pearson Education Limited: Edinburg gate, Harlow, Essex, CM20 2JE, England.

[12] Swaminathan, Vanitha.,Stilley, Karen M., \& Ahluwalia, Rohini. (2009). When Brand Personality Matters: The Moderating Role of Attachment Styles. Journal of Consumer Research.

[13] Wijanto, Setyo H. (2008). "Structural Equation Modeling dengan Lisrel 8.8: Konsep dan Tutorial." Yogyakarta: Graha Ilmu.

[14] Zaichkowsky, Judith Lynne. \& Simpson, Richard Neil. (1996), The Effect of Experience with a Brand Imitator on the Original Brand. Marketing Letter, pp. 31-39. 